\title{
Enhancing Electrocoagulation Process Efficiency Using Astraglus Gossypinus Tragacanth in Turbidity Removal from Brackish Water Samples
}

\author{
Amin Zarei ${ }^{1}$, Hamed Biglari2 ${ }^{*}$, Mohammad Mobini ${ }^{3}$, Gholamreza Ebrahimzadeh ${ }^{4}$, \\ Ahmad Reza Yari ${ }^{5}$, Mohammad Reza Narooie ${ }^{6}$, Ehsan Abouee Mehrizi ${ }^{7}$, \\ Abdollah Dargahi ${ }^{8}$, Mohammad Mehdi Baneshi $^{9}$, Mohammad Javad Mohammadi ${ }^{10}$, \\ Sajad Mazloomi1
}

${ }^{1}$ Department of Environmental Health Engineering, School of Health, Torbat Heydariyeh University of Medical Sciences, Torbat Heydariyeh, Iran

${ }^{2}$ Department of Environmental Health Engineering, School of Public Health, Gonabad University of Medical Sciences, Gonabad, Iran

${ }^{3}$ Department of Environmental Health Engineering, School of Health, Rafsanjan University of Medical Sciences, Rafsanjan, Iran

${ }^{4}$ Department of Environmental Health Engineering, School of Public Health, Zabol University of Medical Sciences, Zabol, Iran

${ }^{5}$ Research Center for Environmental Pollutants, Qom University of Medical Sciences, Qom, Iran ${ }^{6}$ Department of Environmental Health Engineering, School of Public Health, Iranshahr University of Medical Sciences, Iranshahr, Iran

${ }^{7}$ Department of Environmental Health Engineering, Faculty of Public Health, North Khorasan University of Medical Sciences, Bojnurd, Iran

${ }^{8}$ Department of Environmental Health Engineering, School of Health, Kermanshah University of Medical Sciences, Kermanshah, Iran

${ }^{9}$ Social Determinants of Health Research Center, Yasuj University of Medical Sciences, Yasuj, Iran

${ }^{10}$ Student Research Committee, Department of Environmental Health Engineering, School of Public Health and Environmental Technologies Research Center, Ahvaz Jundishapur University of Medical Sciences, Ahvaz, Iran

${ }^{11}$ Department of Environmental Health Engineering, Faculty of Health, Ilam University of Medical Sciences, Ilam, Iran 


\begin{abstract}
Colloidal particles are the main cause of turbidity in an aquatic environment. Water turbidity maintains pathogenic microorganisms against disinfection. In addition to increasing the consumption of antiseptic substances, mainly it causes a lot of aesthetic and non-sanitary problems such as the formation of toxic and carcinogenic side constituents in the treatment of water. In this study we investigated the efficiency of the use of tragacanth of Astraglus gossypinus (Catira) on the effectiveness of the electrocoagulation process in the removal of turbidity from brackish water. In this descriptive-analytic study, direct bentonite injections of 2 to $8 \mathrm{~g} / \mathrm{L}$ were used to provide opacity. In the following, the effect of applying coagulant aid of Tragacanth of Astraglus gossypinus plant with values of 0.25 to $1.5 \mathrm{~g} / \mathrm{L}$ on the efficiency of the electro-coagulation process equipped with iron electrodes in the removal of opacity from brackish water samples were examined in potential difference from 5 to 30 volts, and $\mathrm{pH}$ from 2 to 9 over a period of $60 \mathrm{~min}$. Variation of turbidity was determined using the turbidity sensor in accordance with standard reference methods. The results showed that the highest opacity removal efficiency is about $99 \%$ for each $1 \mathrm{~kg}$ of opacity due to the addition of $7 \mathrm{~g} / \mathrm{L}$ bentonite under neutral $\mathrm{pH}$ conditions, Tragacanth dose of $1.5 \mathrm{~g} / \mathrm{L}, 8 \mathrm{~g} / \mathrm{L}$ dose of $\mathrm{NaCl}$, and voltage of $30 \mathrm{~V}$ for $30 \mathrm{~min}$, along with the average consumption of iron and electrical energy of $0.18 \mathrm{~kg}$ and $0.53 \mathrm{Kwh}$, respectively. Thus, the use of Astraglus gossypinus tragacanth for removing turbidity as a natural coagulant aid dramatically improves the electrocoagulation process efficiency in the removal of turbidity from brackish water samples and reduces current costs of the electro-coagulation process.
\end{abstract}

Keywords: turbidity, aid coagulant, Astraglus gossypinus, Tragacanth, electrocoagulation, brackish water, catira

\section{Introduction}

Health promotion and environmental protection are always dependent on the availability of clean water [1-5]. Today the topic of optimal and affordable water purification is one of the most serious problems of researchers in the world [6-8]. This issue threatens the health and safety of citizens in developing countries at macro levels of management due to the inability to fully control water purification and the crisis of non-sanitary problems [9-12]. Removing suspended particles and colloids is one of the most significant stages of water purification that is performed during the set of processes and operations, including coagulation, flocculation, and sedimentation [13-15]. High water turbidity can cause microorganisms to be maintained against the effect of antiseptic substances and lead to the growth of bacteria, as well as increase the amount of needed antiseptic substances. For effective disinfection, it is better to have less opacity than one NTU. Also, turbidity of more than NTU 5 is detectable and leads to consumer complaints [16-18]. Turbidity in the water is generally created by suspended matter like soil and mud, fine organic and mineral substances, soluble colored organic compounds, plankton, and other microorganisms [19]. In recent years, attention to the removal of turbidity has become more important because of the connection between opacity factors with microorganisms such as giardia and cryptosporidium [20].

Coagulation and flocculation play an important role in surface water treatment. This process enhances the efficiency of following processes by reducing opacity in water purification, including filtration and disinfection [21]. Using coagulant in addition to the primary coagulant and improving the quality of treated water has other benefits such as water enrichment, more successful disinfection, and the resulting sludge density [22-23]. In order to eliminate health problems and reduce production costs as well as the use of synthetic coagulants, numerous research regarding the use of natural coagulants has been carried out so far [14, 24].

The history of using different parts of plant materials such as bark, roots, stems, and seeds for water clarification is related to a book written in Sanskrit 4,000 years ago in India. Indians implemented the seeds of a nirmali tree to clear up turbid water of rivers [25]. Also, water was cleared up traditionally in Peru by a slimy sap of cactus leaves with optimum efficiency [26]. So far, the effectiveness and usability of banana peel, cumin plant, guar gum, Chinese hibiscus, fenugreek and lentils, okra, tea, rice, chitosan, etc. have been examined in water purification and as coagulant aids in various studies [27-32]. Several processes like electro-coagulation (EC) have been introduced [33]. The EC process is one of the most common processes that relies on the foundation coagulation and flocculation. It is an electrochemical process that uses direct current (DC) for the production of original metal coagulants [33]. In the EC process, coagulant is produced by direct flow from the anode electrode during the reaction of electrolytic oxidation [34]. EC is an electrochemical process that uses DC for the production of primary metal coagulants [33]. In the EC process, the coagulant is produced through the DC of the anode electrode during the reaction of electrolytic 
oxidation [34]. The type of produced metal coagulant is dependent on the electrode material and generally is made of iron or aluminum [35]. In this process, pollutants are removed under a set of chemical and physical processes, especially the coagulation process and sedimentation from the water environment [19].

In the meantime, it seems that its coagulant properties are worthy of review due to the jelly tragacanth nature of the Astraglus gossypinus plant. Moreover, its shrub reaches up to a maximum height of one $m$ and it often grows in mountainous regions and arid meadows in a selfpropelled way. Gum materials in stem tissue of the plant species, which are collected and leaked automatically, or due to the creation of a gap are called Tragacanth. Productive species of Tragacanth grow in warm and mountainous areas. More than 900 different species grow in different parts of Iran. Generally, productive varieties of Tragacanth gum are acanaceous, which are referred to as Astrakanta [36]. Tragacanth is counted as one of the most important pasture products. Since ancient times, people have been familiar with its properties and used it in various industries [37-38]. In various studies, the effects of using natural coagulants on the efficiency of the EC process in the removal of various pollutants has been investigated [39-41]. Given that large quantities of tragacanth are produced and collected in different places especially in Iran currently, initial and processing costs are negligible. So it should be considered to be a naturally inexpensive coagulant from this perspective. Therefore, efficiently using tragacanth of Astraglus gossypinus plant as a natural coagulant was investigated in this study on the efficiency of the electro-coagulation process for removing turbidity from brackish waters.

\section{Materials and Methods}

All chemicals used in this study were provided from the Merck brand in Germany. Applied coagulant aids in this study are a gum plant with the scientific name of Astraglus gossypinus. Design, manufacture, and operation of an electro-coagulation reactor was conducted in bipolar form by a closed method. The reactor was manufactured in dimensions of $13 * 12 * 13$ $\mathrm{cm}$ from unbreakable and acid corrosion-resistant glass (buccal) with an effective volume of one 1. Then it was used after being equipped with 4 plate electrodes of iron with thickness of $2 \mathrm{~mm}$, area $121 \mathrm{~cm}^{2}$, and spacing of $2 \mathrm{~cm}$ from each other. Required voltage was supplied to convert urban electric power alternating current (AC) to DC by a transformer with a maximum power of 30 $\mathrm{V}$ and 5 amps current. Turbidity removal in the process of EC was investigated by changing the parameters of 2-10 $\mathrm{pH}$ by $\mathrm{H}_{2} \mathrm{SO}_{4}$ and $\mathrm{NaOH}$ of 0.1 normal, $2-7 \mathrm{~g} / \mathrm{L}$ dose of bentonite to make opacity, electric conductivity by adding sodium chloride $2-8 \mathrm{~g} / \mathrm{L}$, and the dose of Tragacanth was 0.25 to $1.5 \mathrm{~g} / \mathrm{L}$ for a reaction time of maximum $60 \mathrm{~min} .100 \mathrm{~g}$ of Astraglus gossypinus Tragacanth was dried and powdered to prepare the solution of Tragacanth, and it was weighed accurately. It reached a volume of $100 \mathrm{~mL}$ after mixing with $10 \mathrm{~mL}$ of chloride acid of $0.1 \mathrm{~mol}$ using distilled water. Then it was kept in the refrigerator as long as needed. Each one $\mathrm{mL}$ of this solution contained one $g$ of tragacanth [42].

To provide brackish water and examine the effect of other parameters as well as to provide minimal electrical conductivity of solvent, the specified amount of pure $\mathrm{NaCl}$ was added to all samples at the beginning of the process. After beginning the process and passing certain amount of time, samples were taken from the middle of the reactor. Variation of opacity values in accordance with standard methods using the portable turbidity meter (AL250T model, Aqualytic, made in Germany) was investigated after applying sedimentation time for 30 min. All experiments were performed discontinuously with 3 repetitions. It has been reported in some studies that $\mathrm{pH}$ adjustment during the process of clots' production makes hydroxyl different. Therefore, no $\mathrm{pH}$ adjustment was made after the onset of the process in this study [43]. Considering the importance of the amount of electrical energy as well as the weight of the used electrode from economic and system performance aspects, the rate was calculated and presented using the following formulas [41]:

$$
E=\frac{I \cdot \int_{0}^{t} U \cdot d t}{V \cdot C_{0} \cdot \frac{Y_{t}}{100}}
$$

...where $\mathrm{E}$ is the consuming energy $(\mathrm{kWh} / \mathrm{kg})$, I is current intensity $(\mathrm{A})$, voltage $(\mathrm{V}), \mathrm{t}$ is time $(\mathrm{h}), \mathrm{V}$ is the volume of the treated solution $(\mathrm{L})$, and $\mathrm{Y}_{\mathrm{t}}$ is color removal efficiency at time $\mathrm{t}(\%)$.

$$
M=\frac{3600 . I \cdot t \cdot A}{n \cdot F \cdot V \cdot C_{0} \cdot \frac{Y_{t}}{100}}
$$

...where $\mathrm{M}$ is the unit electrode material demand $(\mathrm{kg} / \mathrm{kg}), \mathrm{t}$ is time $(\mathrm{h}), \mathrm{n}$ is the number of electrons involved in the oxidation/reduction reaction, $\mathrm{F}$ is Faraday's constant $(\mathrm{C} / \mathrm{mol})$, and $\mathrm{A}$ is atomic mass of the electrode material $(\mathrm{g} / \mathrm{mol})$.

\section{Results and Discussion}

\section{Effect of Primary pH Change}

Each coagulant substance with a certain concentration in an optimum $\mathrm{pH}$ in the process of coagulation and flocculation has the highest rate of efficiency in the shortest possible time with the significant possible returns. Thus, examining the $\mathrm{pH}$ effect of aqueous solutions is considered one of the key and effective factors in chemical coagulation processes [27]. In many studies, the effect of $\mathrm{pH}$ on the efficacy of removing 
pollutants in the process of chemical coagulation and its effect depending on the type of pollutant as well as the used process were mentioned [44]. The efficiency of simultaneously using the tragacanth and the EC process are shown Fig. 1 in removing the opacity at different $\mathrm{pH}$ values. Results indicate that the highest rate of opacity removal efficiency from aqueous solution occurred at neutral $\mathrm{pH}$, and that efficiency at lower or higher $\mathrm{pH}$ was decreased. Based on the study carried out by Bazrafshan et al. [35], clots are significantly larger at optimal $\mathrm{pH}$ and the process of coagulation-sedimentation is more efficient. Hence, the dominant mechanism of coagulationsedimentation in a sweep coagulation mechanism is the trapping of suspended particles in the polymer chains of a coagulant substance.

It has also been reported in other studies that most iron ions at neutral $\mathrm{pH}$ are effectively gelatinous clots of sedimentary $\mathrm{Fe}(\mathrm{OH})_{3}[33,45]$. Findings of the study by Bazrafshan et al. [35] specify that the formation of iron hydroxide clots is decreased at a $\mathrm{pH}$ below and above the optimal $\mathrm{pH}$ and, consequently, efficiency is also reduced. Removing a hydrocarbon pollutant from Sewage using the electrical coagulation process was investigated by Tir et al. [46], whose findings indicate that efficiency of the process was almost constant at $\mathrm{pH} 6$ and 7 , while reducing efficiency was very significant outside of this range. Removing oily sewage from a restaurant by electrical coagulation process was examined by $\mathrm{Xu}$ et al. [47], and the best removal efficiency was achieved and stated in the neutral $\mathrm{pH}$ range. It was also reported in a study by De Carvalho et al. [41] that the most effective combination of EC and Moringa oleifera seeds in removal of acid black 1 and basic red 2 colors occurred in the neutral $\mathrm{pH}$ range. It was believed by Abuzaid et al. [48] that although the mechanism of coagulation using iron salts occurred in the $\mathrm{pH}$ range, the formless hydrocarbon ferric clots were obtained at $\mathrm{pH} 8$ and they have the least solubility. Therefore, the $\mathrm{pH}$ increase caused by the exhaust of hydrogen gas will increase the efficiency of the EC

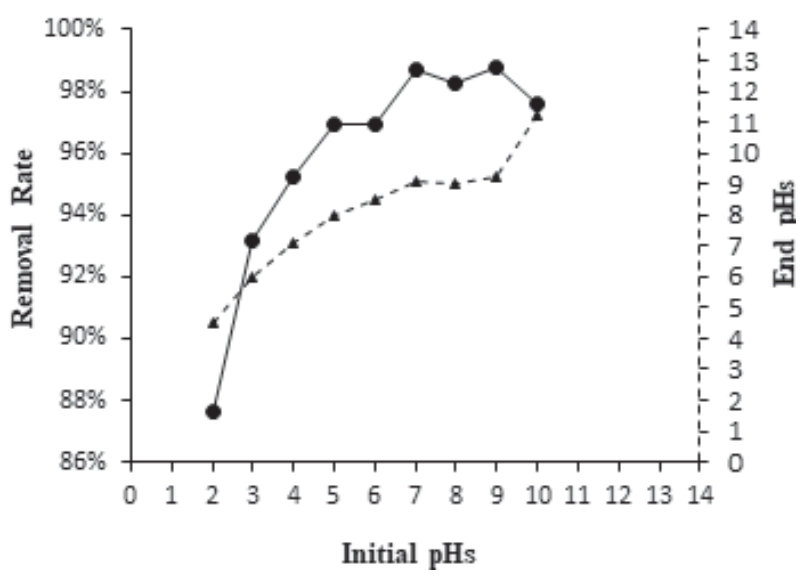

Fig. 1. Effect of $\mathrm{pH}$ on turbidity removal efficiency and $\mathrm{pH}$ changes (bentonite $7 \mathrm{~g} / \mathrm{L}$, tragacanth $1.5 \mathrm{~g} / \mathrm{L}, \mathrm{NaCl} 8 \mathrm{~g} / \mathrm{L}$, voltage $30 \mathrm{~V}$, and time $30 \mathrm{~min}$ ). process. In this study, adding tragacanth to solution did not cause any change in the $\mathrm{pH}$ environment, but during the electrical coagulation process over time in addition the temperature rise from 19 to $25^{\circ} \mathrm{C}$ and the average $\mathrm{pH}$ increased about 0.26 with a standard deviation of 1.03 units. The $\mathrm{pH}$ was augmented from about 7 to about 9.1 (after $60 \mathrm{~min}$, from the beginning of process). The findings of this study are consistent with the outcomes of other studies [40-41, 43, 48].

\section{The Effect of Changing the Reaction Time}

The effect of changes in reaction time on opacity removal efficiency is shown in Fig. 2. Based on the outcomes, increases in the time spent for turbidity removal up to 30 min was done linearly up to about $99 \%$ and then dropped to about $61 \%$. This can be due to the growth of $\mathrm{pH}$ as well as the outflow of hydrogen gas and, as a result, floating of the material [48]. On the other hand, increasing $\mathrm{pH}$ may have disrupted the environment of producing iron hydroxyl clots [41]. Since temperature was also continuous during the process and increased by about $6^{\circ} \mathrm{C}$, that also could lead to dissolution of deposited substances [35]. It was believed by Abuzaid et al. [48] that the large amount of coagulant in the process of EC at long-term exposure was produced, which resulted in the induction of charge reversal and the re-stabilization of some of the colloids in the process environment.

\section{Effect of Change on Primary Conductivity and Voltage}

The effect of change of primary electrical conductivity and voltage on opacity removal efficiency was investigated. Maximum efficiency was observed in 30,15 , and $5 \mathrm{~V}$ by about $0.99,0.90$, and $0.82 \%$, respectively. Results show that removal efficiency increased dramatically with increasing electrical conductivity and voltage. In this study, the effect of

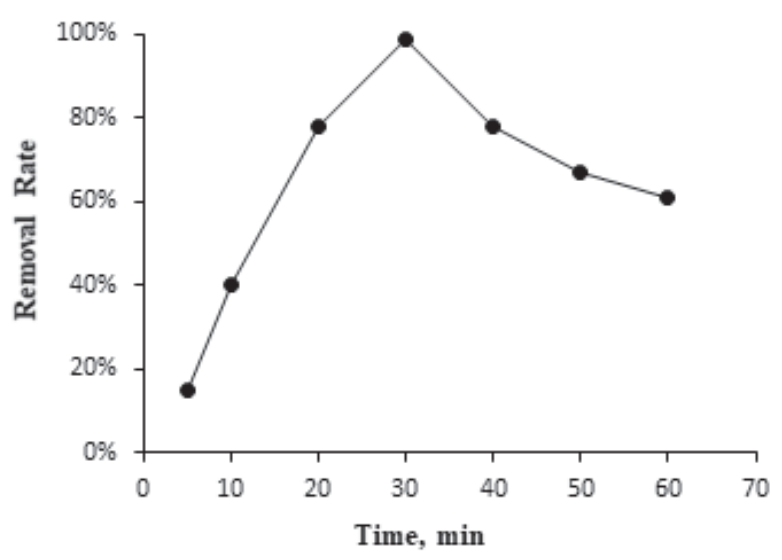

Fig. 2. Effect of reaction times on turbidity removal efficiency (bentonite $7 \mathrm{~g} / \mathrm{L}, \mathrm{pH} 7$, tragacanth $1.5 \mathrm{~g} / \mathrm{L}, \mathrm{NaCl} 8 \mathrm{~g} / \mathrm{L}$, and voltage $30 \mathrm{~V}$ ). 
changing the initial electrical conductivity was checked out by adding specific amounts of sodium chloride and, in accordance with other parameters, holding other variables constant (Fig. 3). There is always a direct correlation between the amount of produced coagulant of electrodes and the parameter of electrical conductivity as well as voltage. Increased electrical conductivity facilitates the flow of electricity between the electrodes (reduction in resistance), which leads to the production of more coagulants and reduces the current costs of the process [40]. Natural water resources contain different compounds and ions.

In the case of creating an electrical bridge in such water environments, available ions cause transmission of electrical current within the bridge. The greater the ionic strength of these species, the more the stream transfer at constant voltage. In a steady stream, the voltage level is reduced with increasing electrical conductivity and vice versa [23]. According to Faraday's law, the production of metal hydroxyls is augmented by increasing the current density. Thus, more active venues will be formed to attract more efficient pollutants [34]. Based on the perspective of Baneshi et al. [33], coagulant production leads to augmentation of electrical conductivity by increasing the reaction time in the process of EC, which has a good effect on improving process efficiency. It has been stated in some studies that high amounts of sodium chloride cause more hydrogen gas to flow out of the system under process. As a result, the $\mathrm{pH}$ of the environment has increased and the dissolution of the metal clot is dropped. Moreover, the removal efficiency is also boosted [48]. It is believed by Adjeroud et al. [40] that adding sodium chloride to provide electrical conductivity in the process of EC by producing chloride ions significantly reduces the adverse effects of bicarbonate and sulfate ions on the process. In the current research, increases in the rate of sodium chloride to solution not only causes growth in removal efficiency but also leads to a decline in current system costs by reducing the amount of electrical power consumption, which is consistent

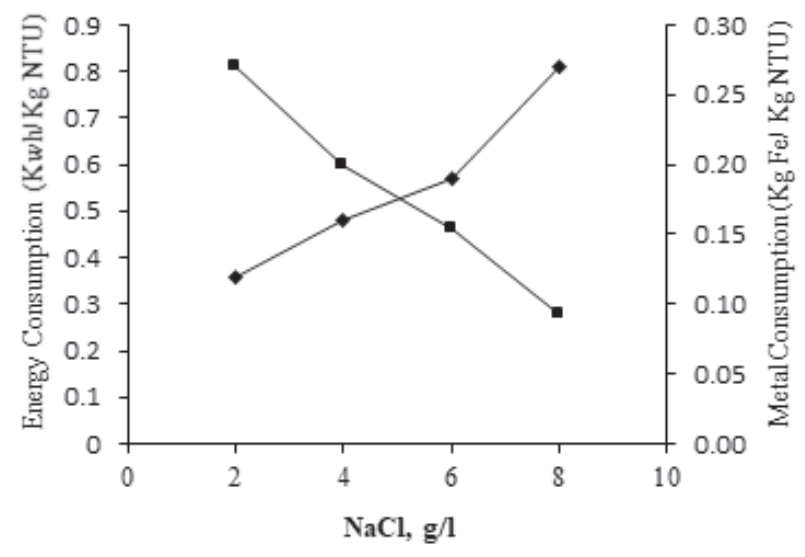

Fig. 3. Effect of energy and metal consumed in different initial electrical conductivity (bentonite $7 \mathrm{~g} / \mathrm{L}, \mathrm{pH} 7$, tragacanth $1.5 \mathrm{~g} / \mathrm{L}$, voltage $30 \mathrm{~V}$, and $30 \mathrm{~min}$ ). with the findings of the above studies and other research [49-50].

\section{Effect of Change on Tragacanth Dosage (Catira)}

Removal turbidity efficiency for catira and the EC/catira process in the case of using different doses is shown in Fig. 4. The results indicated that adding tragacanth to the solution in the EC/catira process at concentrations of less than $0.75 \mathrm{~g} / \mathrm{L}$ are sufficient for optimal efficiency. However, improving effectiveness and achieving a high rate of efficiency has been intensified in concentrations greater than this amount over a shorter period of time. When using a dose of $0.75 \mathrm{~g} / \mathrm{L}$ of tragacanth in the process of EC/catira, removal efficiency reached about $94 \%$ after about $30 \mathrm{~min}$. While the removal efficiency reached up to $94 \%$ using a dose of $1.5 \mathrm{~g} / \mathrm{L}$ only during $20 \mathrm{~min}$ and more than $99 \%$ of the turbidity was removed from the solution after $30 \mathrm{~min}$. Therefore, if the reaction time is increased, a lower rate of doses can be used to achieve optimal efficiency. Using a dose of $1.5 \mathrm{mg} / \mathrm{L}$ of tragacanth can dramatically remove about $46 \%$ of opacity only after a period of $30 \mathrm{~min}$.

In the study of coagulation of azo dyes using the Olivier Moringa seed extract by Beltrán-Heredia et al. [51], it was thought that the use of high doses of natural coagulant aids might remain in the environment and process in form of a solution without coagulation in solution, which could cause secondary problems in the process. Also, the use of doses of less than $0.6 \mathrm{~g} / \mathrm{L}$ of the absorber of Olivier Moringa seed extract along with the EC process was considered effective and sufficient by De Carvalho et al. [41], to remove the acid black 1 and basic red 2 colors. It was believed by Nawel et al. [40] that the capacity of a natural coagulant depends on the activity of its mucilage. Therefore, they examined the effect of simultaneous use of cactus extract and the process of EC on the purification of wastewater. The outcome of their study represented the use of small amounts of this

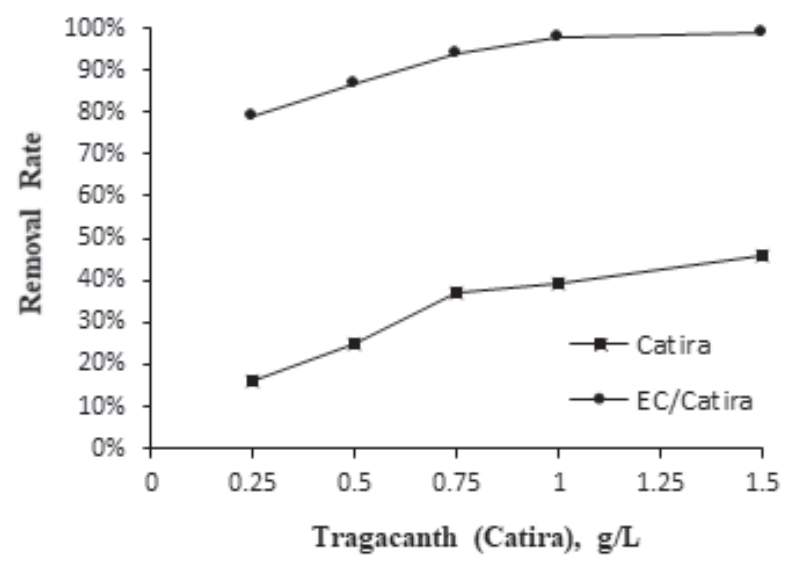

Fig. 4. Effect of the catira dosage on turbidity removal efficiency (bentonite $7 \mathrm{~g} / \mathrm{L}, \mathrm{pH} 7, \mathrm{NaCl} 8 \mathrm{~g} / \mathrm{L}$, voltage $30 \mathrm{~V}$, and $30 \mathrm{~min}$ ). 
plant extract has improved the efficiency of wastewater treatment so that in the case of using only $0.016 \mathrm{ml} / \mathrm{L}$ of Opuntia ficus indica extract in initial $\mathrm{pH}$ condition of 8.2 , electrical conductivity of $3.04 \mathrm{mS} / \mathrm{cm}$, and current density of $43.6 \mathrm{~mA} / \mathrm{cm}^{2}$, removal efficiency of turbidity has improved from $72 \%$ to about $87 \%$. It was pointed out in some studies that such natural coagulants using physical absorption methods due to mucilage spreading in the water environment remove opacity agents. Removal efficiency also increases by increasing the amount of mucilage, and the findings of this study are consistent with their findings [40, 52-53].

\section{Effect of Primary Bentonite Change (Initial Turbidity)}

In this study, process efficiency was examined by changing initial turbidity due to the addition of 3,5 , and $7 \mathrm{~g} / \mathrm{L}$ bentonite to the solution which was subjected to the process. The results displayed the integration system of tragacanth and EC in more turbid volumes was more efficient and thus removal efficiency was improved. So that removal efficiency of turbidity in quantities of 5 and $7 \mathrm{~g} / \mathrm{L}$ bentonite 2 reached 82, 94, and 99\%, respectively.

Efficiency of the Moringa oleifera seeds and polyaluminum Chloride on removing turbidity from the water was examined by Bina et al. [54], who found that increasing the unit of turbidity led to augmentation in its efficiency of removal by Moringa seed extract. Based on their point of view, the cause of this occurrence was a mechanism of absorbing and neutralizing loads. Efficiency of the EC process in the removal of opacity due to the use of bentonite was investigated by Abuzaid et al. [48], and it was reported that increasing the initial values of opacity (swelling the initial values of bentonite) leads to improvement in process efficiency because of overcoming sedimentation mechanisms. The results of these studies are in line with the results of the current study. Using biological coagulant of tragacanth instead of synthetic ones minimizes serious damage to the environment.

\section{Conclusions}

The results showed that using astraglus gossypinus tragacanth as a natural coagulant is effective for the electrocoagulation process in turbidity removal from brackish water samples. The highest removal efficiency was about $99 \%$ for each $1 \mathrm{~kg}$ NTU due to the addition of $7 \mathrm{~g} / \mathrm{L}$ bentonite under neutral $\mathrm{pH}$ conditions, tragacanth dose of $1.5 \mathrm{~g} / \mathrm{L}, 8 \mathrm{~g} / \mathrm{L}$ dose of $\mathrm{NaCl}$, voltage of $30 \mathrm{~V}$ for $30 \mathrm{~min}$, and average consumption of iron and electrical energy of $0.18 \mathrm{~kg}$ and $0.53 \mathrm{Kwh}$, respectively. The use of Astraglus gossypinus tragacanth in removing turbidity as a natural coagulant aid dramatically improves electrocoagulation process efficiency in the removal of turbidity from brackish water samples and reduces current costs of the electro-coagulation process.
The use of these bio-coagulants instead of synthetic suppliers could reduce the risk of serious damage to the environment.

\section{Acknowledgements}

We would like to thank Gonabad University of Medical Sciences for funding and all colleagues who have collaborated on writing this paper.

\section{Ethical Clearance}

Taken from the ethical committee of Gonabad University of Medical Science with grant Nos. 94/58 by the Student Research Committee.

\section{References}

1. AHAMADABADI M., SAEIDI M., RAHDAR S., NAROOIE MR., SALIMI A., ALIPOUR V., KHAKSEFIDI R., BANESHI MM., BIGLARI H. Assessment of the chemical quality of groundwater resources in Chabahaar City using GIS software in 2016. Res. J. Appl. Sci. 11, 1399, 2016.

2. ALIPOUR V., REZAEI L., ETESAMIRAD MR., RAHDAR S., NAROOIE MR., SALIMI A., HASANI J., KHAKSEFIDI R., SADAT SA., BIGLARI H. Feasibility and applicability of solar disinfection (SODIS) for point-ofuse water treatment in Bandar Abbas, South of Iran. J. Glob. Pharma Technol. 9, 40, 2017.

3. BIGLARI H., CHAVOSHANI A., JAVAN N., HOSSEIN MAHVI A. Geochemical study of groundwater conditions with special emphasis on fluoride concentration, Iran. Desalin. Water Treat. 57, 22392, 2016.

4. MIRZABEYGI M., NAJI M., YOUSEFI N., SHAMS M., BIGLARI H., MAHVI AH. Evaluation of corrosion and scaling tendency indices in water distribution system: a case study of Torbat Heydariye, Iran. Desalin. Water Treat. 57, 25918, 2016.

5. MORADI M., SAFARI Y., BIGLARI H., GHAYEBZADEH M., DARVISHMOTEVALLI M., FALLAH M., NESARI S., SHARAFI H. Multi-year assessment of drought changes in the Kermanshah city by standardized precipitation index. Int. J. Pharm. Technol. 8, 17975, 2016.

6. ALIPOUR V., ETESAMIRAD MR., RAHDAR S. NAROOIE MR., SALIMI A., HASANI J., KHAKSEFIDI R., SADAT SA., BIGLARI H. Introduction of red soil (ocher) of hormoz Island as a natural adsorbent to removal of cadmium from aqueous solutions. J. Glob. Pharma Technol. 9, 17, 2017.

7. BIGLARI H., SAEIDI M., ALIPOUR V., RAHDAR S., SOHRABI Y., KHAKSEFIDI R., NAROOIE MR., ZAREI A., AHAMADABADI M. Review on hydrochemical and health effects of it in Sistan and Baluchistan groundwater's,Iran. Int. J. Pharm. Technol. 8, 17900, 2016.

8. DARGAHI A., GOLESTANIFAR H., DARVISHI P., KARAMI A., HASAN SH., POORMOHAMMADI A., BEHZADNIA A. An Investigation and Comparison of Removing Heavy Metals (Lead and Chromium) from 
Aqueous Solutions Using Magnesium Oxide Nanoparticles. Pol J Environ Stud. 25, 2, 2016.

9. BIGLARI H., GERAVANDI S., MOHAMMADI MJ., PORAZMEY EJ., CHUTURKOVA RZ., KHANIABADI YO., GOUDARZI G., MAHBOUBI M., MOHAMMADI B., YARI AR. Relationship between air particulate matter \& meteorological parameters. Fresenius Environ. Bull. 26, 4047, 2017.

10. KHAKSEFIDI R., BIGLARI H., RAHDAR S., BANESHI MM., AHAMADABADI M., NAROOIE MR., SALIMI A., SAEIDI M., ALIPOUR V. The removal of phenol from aqueous solutions using modified saxaul ASH. Res. J. Appl. Sci. 11, 1404, 2016.

11. PIRSAHEB M., REZAI Z., MANSOURI A., RASTEGAR A., ALAHABADI A., SANI AR., SHARAFI K. Preparation of the activated carbon from India shrub wood and their application for methylene blue removal: modeling and optimization. Desalin. Water Treat. 57, 5888, 2016.

12. SOHRABI Y., SAEIDI M., BIGLARI H., RAHDAR S., BANESHI MM., AHAMADABADI M., NAROOIE MR., KHAKSEFIDI R., ALIPOUR V. Heavy metal concentrations in water resources of rural areas of Kermanshah, Iran. IIOAB J. 7, 542, 2016.

13. BIGLARI H., AFSHARNIA M., ALIPOUR V., KHOSRAVI R., SHARAFI K., MAHVI AH. A review and investigation of the effect of nanophotocatalytic ozonation process for phenolic compound removal from real effluent of pulp and paper industry. Environ. Sci. Pollut. Res. Int. 24, 4105, 2017.

14. NAROOIE MR., RAHDAR S., BIGLARI H., BANESHI MM., AHAMADABADI M., SAEIDI M., SALIMI A., KHAKSEFIDI R., ALIPOUR V. Evaluate the efficiency of ashes from palm and pistachio wastes in removal of reactive red 120 dye from aqueous. J. Appl. Sci. 11, 1411, 2016.

15. SRINIVASAN PVIRARAGHAVAN T. Characterisation and concentration profile of aluminium during drinkingwater treatment. Water SA. 28, 99, 2002.

16. BIGLARI H., SAEIDI M., RAHDAR S., NAROOIE MR., SALIMI A., KHAKSEFIDI R., BANESHI MM., AHAMADABADI M., ALIPOUR V. Evaluation of corrosion and scaling tendency indices in Zahedan groundwater resources. IIOAB J. 7, 523, 2016.

17. BILOTTA P., STEINMETZ RLR., KUNZ A., MORES R. Swine effluent post-treatment by alkaline control and UV radiation combined for water reuse. J. Clean. Prod. 140, 1247, 2017.

18. HAYDAR S., ARSHAD M., AZIZ J. Evaluation of drinking water quality in urban areas of Pakistan: A case study of Southern Lahore. Pakistan J. Eng. Appl. Sci. 2016.

19. BUSTAMANTE J., PACIOS F., DÍAZ-DELGADO R., ARAGONÉS D. Predictive models of turbidity and water depth in the Doñana marshes using Landsat TM and ETM+ images. J. Environ. Manage. 90, 2219, 2009.

20. RAMO A., DEL CACHO E., SÁNCHEZ-ACEDO C., QUÍLEZ J. Occurrence of Cryptosporidium and Giardia in raw and finished drinking water in north-eastern Spain. Sci. Total Environ. 580, 1007, 2017.

21. BIGLARI H., SAEIDI M., ALIPOUR V., RAHDAR S., SOHRABI Y., KHAKSEFIDI R., NAROOIE MR., ZAREI A., AHAMADABADI M. Prospect of disinfection byproducts in water resources of Zabol. Int. J. Pharm. Technol. 8, 17856, 2016.

22. KHOSRAVI R., HOSSINI H., HEIDARI M., FAZLZADEH M., BIGLARI H., TAGHIZADEH A., BARIKBIN B.
Electrochemical Decolorization of Reactive Dye from Synthetic Wastewater by Mono-Polar Aluminum Electrodes System. Int. J. Electrochem. Sci. 12, 4745, 2017.

23. WANG W., YUE Q., LI R., SONG W., GAO B., SHEN $\mathrm{X}$. Investigating coagulation behavior of chitosan with different Al species dual-coagulants in dye wastewater treatment. J. Taiwan Inst. Chem. Eng. 2017.

24. BIGLARI H., SOHRABI Y., CHARGANEH SS., DABIRIAN M., JAVAN N. Surveying the geographical distribution of aluminium concentration in groundwater resources of sistan and baluchistan, Iran Res. J. Med. Sci. 10, 351, 2016.

25. JODI M., BIRNIN-YAURI U., YAHAYA Y., SOKOTO M. The use of some plants in water purification. Glob. Adv. Res. J. Chem. Mater. Sci. 4, 071, 2012.

26. NDABIGENGESERE ANARASIAH KS. Quality of water treated by coagulation using Moringa oleifera seeds. Water Res. 32, 781, 1998.

27. BIGLARI H., SAEIDI M., SOHRABI Y., KHAKSEFIDI R., RAHDAR S., NAROOIE MR., ALIPOUR V., ZAREI A., AHAMADABADI M. Persica a miracle in the protect and promote oral and dental health. Int. J. Pharm. Technol. 8, 17957, 2016.

28. KUMAR V., OTHMAN N., ASHARUDDIN S. Applications of Natural Coagulants to Treat Wastewater A Reviewin MATEC Web Conf. EDP Sciences. 2017.

29. RAHDAR S., AHAMADABADI M., KHAKSEFIDI R., SAEIDI M., NAROOIE MR., SALIMI A., BIGLARI H., BANESHI MM. Evaluation of phenol removal from aqueous solution by banana leaf ash. J. Glob. Pharma Technol. 9, 20, 2017.

30. RAHDAR S., KHAKSEFIDI R., ALIPOUR V., SAEIDI M., NAROOIE MR., SALIMI A., BIGLARI H., BANESHI MM., AHAMADABADI M. Phenol adsorptive by cumin straw ash from aqueous environments. IIOAB J. 7, 536, 2016.

31. SAEIDI M., BIGLARI H., RAHDAR S., BANESHI MM., AHAMADABADI M., NAROOIE MR., SALIMI A., KHAKSEFIDI R. The adsorptive acid orange 7 using Kenya tea pulps ash from aqueous environments. J. Glob. Pharma Technol. 9, 13, 2017.

32. ZHANG J., ZHANG F., LUO Y., YANG H. A preliminary study on cactus as coagulant in water treatment. Process Biochem. 41, 730, 2006.

33. BANESHI MM., NARAGHI B., RAHDAR S., BIGLARI H., SAEIDI M., AHAMADABADI M., NAROOIE MR., SALIMI A., KHAKSEFIDI R., ALIPOUR V. Removal of remazol black B dye from aqueous solution by electrocoagulation equipped with iron and aluminium electrodes. IIOAB J. 7, 529, 2016.

34. BAZRAFSHAN E., BIGLARI H., MAHVI AH. Phenol removal by electrocoagulation process from aqueous solutions. Fresenius Environ. Bull. 21, 364, 2012.

35. BAZRAFSHAN E., BIGLARIH., MAHVI AH. Humic acid removal from aqueous environments by electrocoagulation process using iron electrodes. E-Journal Chem. 9, 2453, 2012.

36. MAASSOUMI A.A. The genus Astragalus in Iran. Research Institute of Forests and Rangelands Tehran. 2, 1989.

37. DABESTANI M., KADKHODAEE R., PHILliPS GO., ABBASI S. Persian gum: A comprehensive review on its physicochemical and functional properties. Food Hydrocoll. 2017.

38. SINGH B., VARSHNEY L., FRANCIS S. Synthesis and characterization of tragacanth gum based hydrogels by 
radiation method for use in wound dressing application. Radiat. Phys. Chem. 135, 94, 2017.

39. ADJEROUD N., DAHMOUNE F., MERZOUK B., LECLERC J-P., MADANI K. Improvement of electrocoagulation - electroflotation treatment of effluent by addition of Opuntia ficus indica pad juice. Sep. Purif. Technol. 144, 168, 2015.

40. DE CARVALHO HP., HUANG J., NI J., ZHAO M., YANG X., WANG X. Removal of Acid Black 1 and Basic Red 2 from aqueous solutions by electrocoagulation/Moringa oleifera seed adsorption coupling in a batch system. Water Sci. Technol. 72, 203, 2015.

41. SEID-MOHAMMADI A., GH A., SAMMADI M., AHMADIAN M., POORMOHAMMADI A. Removal of humic acid from synthetic water using chitosan as coagulant aid in electrocoagulation process for $\mathrm{Al}$ and $\mathrm{Fe}$ electrodes. Res. J. Chem. Environ. 18, 5, 2014.

42. DIVAKARAN RPILLAI VS. Flocculation of river silt using chitosan. Water Res. 36, 2414, 2002.

43. SECULA MS., CREȚESCU I., PETRESCU S. An experimental study of indigo carmine removal from aqueous solution by electrocoagulation. Desalination. 277, 227, 2011.

44. KALINIICHUK E., VASILENKO I., SHCHEPANYUK VY., SUKHOVERKHOVA N., MAKAROV I. Treating refinery wastewaters to remove emulsified oils by electrocoagulation and electroflotation. Int. Chem. Eng. (United States). 16, 1976.

45. ABDELWAHAB O., AMIN N., EL-ASHTOUKHY E.Z. Electrochemical removal of phenol from oil refinery wastewater. J. Hazard. Mater. 163, 711, 2009.

46. TIR MMOULAI-MOSTEFA N. Optimization of oil removal from oily wastewater by electrocoagulation using response surface method. J. Hazard. Mater. 158, 107, 2008.
47. XU XZHU X. Treatment of refectory oily wastewater by electro-coagulation process. Chemosphere. 56, 889, 2004.

48. ABUZAID NS., BUKHARI AA., AL-HAMOUZ ZM. Removal of bentonite causing turbidity by electro coagulation. J. Environ. Sci. Heal. Part A. 33, 1341, 1998.

49. ALIZADEH-GOLESTANI HLAYEGHIZADEH H. To decrease of turbidity, TSS of waste water of Shahid Hasheminezhad Gas Refinery of Sarakhs in the form of Electrocoagulation. in The First international Conference of Oil, Gas, Petrochemical And Power Plant. 2012.

50. ISANLOO H., MOHSENI SM., NAZARI S., SARKHOSH M., ALIZADEH MATBOO S. Efficiency of electrical coagulation process in reduction of water turbidity. J. Heal. 5, 67, 2014

51. BELTRÁN-HEREDIA JSÁNCHEZ MARTÍN J. Azo dye removal by Moringa oleifera seed extract coagulation. Color. Technol. 124, 310, 2008.

52. MILLER SM., FUGATE EJ., CRAVER VO., SMITH JA., ZIMMERMAN JB. Toward understanding the efficacy and mechanism of Opuntia spp. as a natural coagulant for potential application in water treatment. Environ. Sci. Technol. 42, 4274, 2008.

53. SÁENZ C., SEPÚlVEDA E., MATSUHIRO B. Opuntia spp mucilage's: a functional component with industrial perspectives. J. Arid Environ. 57, 275, 2004.

54. BINA B., SHASAVANI A., ASGHARE G., HASANZADE A. Comparison of water turbidity removal efficiencies of Moringa oleifera seed extract and poly-aluminum chloride. J. water wastewater. 61, 24, 2007. 